\title{
Role of bronchoalveolar lavage in the diagnosis of fat embolism syndrome
}

\author{
N. Roger*, A. Xaubet*, C. Agustí*, E. Zabala**, E. Ballester*, A. Torres*, \\ C. Picado*, R. Rodriguez-Roisin*
}

Role of bronchoalveolar lavage in the diagnosis of fat embolism syndrome. N. Roger, A. Xaubet, A. Agustí, E. Zabala, E. Ballester, A. Torres, C. Picado, R. Rodriguez-Roisin. ERS Journals Ltd 1995.

ABSTRACT: Fat embolism syndrome (FES) is a serious clinical disorder occurring in trauma patients. The diagnosis of fat embolism syndrome may be difficult to establish clinically. We therefore wanted to investigate the usefulness of bronchoalveolar lavage (BAL) in the diagnostic evaluation of fat embolism syndrome.

We analysed the presence of fat droplets in BAL cells in 32 trauma patients (7 with full diagnostic criteria of fat embolism syndrome, 17 with incomplete diagnostic criteria, and 8 with no diagnostic criteria at the time of bronchoscopy), 9 nontrauma patients with acute respiratory failure and radiographic pulmonary infiltrates, and a control group composed of 10 individuals.

An increased percentage of oil red $O$ positive alveolar macrophages (cut-off point $>3 \%$ ) in BAL was found in 6 out of 7 patients with definite clinical criteria of fat embolism syndrome, and in 6 out of 20 trauma patients without the clinical diagnosis of fat embolism syndrome. In two patients with fat embolism syndrome, sequential BAL showed that the percentage of positive macrophages decreased when the clinical manifestations disappeared. An increased number of BAL macrophages with fat droplets was also observed in two trauma patients without evidence of fat embolism syndrome after long-bone surgical intervention. By contrast, all nontrauma patients had a percentage of positive cells lower than $3 \%$.

Our findings suggest that BAL oil red $O$ positive macrophages are frequently observed in trauma patients irrespective of the presence of fat embolism syndrome. Conceivably, a high number of oil red $O$ positive macrophages could reflect clinically silent fat embolization.

Eur Respir J., 1995, 8, 1275-1280.
Serveis de *Pneumologia i Al.lèrgia Respiratòria i **d'Anestiologia i Reanimació (Unitat de Cures Intensives Quirúrgiques (UCIQ)), Hospital Clínic, Departament de Medicina, Universitat de Barcelona, Barcelona, Spain.

Correspondence: A. Xaubet

Servei de Pneumologia i Al.lèrgia Respiratoria Hospital Clinic

Villarroel 170

Barcelona 08036

Spain

Keywords: Acute respiratory failure bronchoalveolar lavage mechanical ventilation oil red $\mathrm{O}$ stain

trauma

Received: November 151994

Accepted after revision April 131995

Supported by a grant from SEPAR-Medical Europa 1992.
Fat embolism syndrome (FES) is a serious clinical disorder occurring in trauma patients, mainly in those with long-bone fractures. The diagnosis of FES is clinically established on the basis of the presence of acute respiratory failure with radiographic pulmonary infiltrates, neurological dysfunction and petechial rash occurring soon after long-bone fractures [1]. However, in some cases, the diagnosis of FES remains uncertain due to the absence of one or more of these criteria. In trauma patients, radiographic pulmonary infiltrates and respiratory failure can have different aetiologies, such as pulmonary infection, pulmonary contusion and aspiration pneumonia. In addition, neurological symptoms are often difficult to evaluate in sedated patients, and may be secondary to concomitant cerebral contusion. Furthermore, the characteristic petechial rash may be absent or its appearance delayed [1]. Several laboratory tests, such as the detection of fat globules in urine and in blood, or the measurement of serum lipase activity, have poor sensitivity and specificity [2-4]. Preliminary results concerning the diagnostic value of the presence of fat droplets in pulmonary capillary blood obtained from a wedged pulmonary catheter have been reported $[5,6]$; however, the specificity and the sensitivity of this invasive technique, which is not always available, has not been established. Therefore, the development of a test which enables the accurate diagnosis of this syndrome could be of clinical interest.

CHASTRE et al. [7] suggested that the identification of fat droplets in cells recovered by bronchoalveolar lavage (BAL) may be both a sensitive and specific tool to establish the diagnosis of FES in trauma patients. However, their findings were not confirmed by VeDRINNE et al. [8], who reported that, apart from FES, other clinical conditions, such as multiple organ failure, sepsis or hypertriglyceridaemia, can be associated with the presence of fat droplets in BAL cells. Thus, based on these findings, the usefulness of BAL in the diagnosis of FES has not been clearly determined.

The present study was thus undertaken to assess the role of BAL in the diagnostic evaluation of FES in trauma patients with and without clinical criteria of the syndrome. 


\section{Materials and methods}

\section{Study population}

The 51 patients studied were divided into 5 groups, characteristics are shown in table 1.

Trauma group. Composed of 32 patients with long-bone and/or pelvis fractures. The trauma group was further classified into three subgroups.

Group 1A - definite FES. This subgroup was composed of seven patients with definite fat embolism syndrome. Patients were included in this group when radiological pulmonary infiltrates and/or acute respiratory failure (defined by an arterial oxygen tension $\left(\mathrm{Pa}_{\mathrm{a}} \mathrm{O}_{2}\right) /$ fractional inspiratory oxygen $\left(F \mathrm{I}, \mathrm{O}_{2}\right)$ ratio $\left.<36.7 \mathrm{kPa}(<275 \mathrm{mmHg})\right)$ and at least one of the other two major diagnostic criteria described by GURD [9] were observed: 1) appearance of a petechial rash; and 2) neurological symptoms unrelated to head injury or other conditions. In patients with either thoracic or head trauma, the presence of petechial rash was required to establish the diagnosis of FES. According to the score (range 1-13) proposed by SCHONFELD et al. [4], the fracture index for these patients was 5.9 2 (range 3-8) and all patients required mechanical ventilation. Five patients had respiratory failure. There were pulmonary infiltrates in all the patients (bilateral in four and unilateral in three), five had neurological symptoms, and six petechial rash. Five patients had associated head or thoracic injuries but all of them developed petechial rash. None of the patients had any evidence of other pulmonary disorders.

Group 1B - incomplete diagnostic criteria for FES. This subgroup was composed of 17 patients with incomplete criteria of FES. These patients fulfilled one of the three major criteria of GURD [9], and FES was suspected, but not confirmed or excluded, when BAL was performed. All but one patient required mechanical ventilation. Four patients with head injury had a petechial rash in the absence of pulmonary manifestations. Thirteen patients had pulmonary infiltrates (10 bilateral) and 10 had acute respiratory failure.
Group 1C - no evidence of FES. This subgroup was composed of eight trauma patients without any criteria of FES. All of them needed mechanical ventilation due to severe head injury. The diagnosis of FES was excluded according to the fat embolism score described by SCHONFELD et al. [4]. If the score remains below 5 in the first 3 days of hospitalization, the diagnosis of FES can probably be excluded. In all patients from this group the fat embolism score was lower than 5 .

Nontrauma patients with lung infiltrates. Nine patients with lung infiltrates were included in this group. All of them required mechanical ventilation when BAL was performed. The aetiology of acute respiratory failure was pneumonia [5], adult respiratory distress syndrome [3] and neurogenic pulmonary oedema [1]. In all the groups, patients with clinical evidence of pulmonary aspiration were excluded from the study.

Control group. This group was composed of 10 subjects with no evidence of diffuse respiratory disease. Fibreoptic bronchoscopy was performed in view of a single episode of haemoptysis with normal chest radiograph, isolated pulmonary node, suspicion of upper airway disease or extrathoracic metastatic lesions, with no additional clinical or radiographic evidence of lung disease. In all patients, bronchoscopy was macroscopically normal.

All patients or their next-of-kin were informed of the characteristics and nature of the study and all gave written informed consent. The study was approved by the Ethics Committee of the Hospital Clinic.

\section{Methods}

Bronchoalveolar lavage was performed with $150 \mathrm{~mL}$ of sterile saline solution as described previously $[10,11]$. The lavage was performed in the middle lobe or in the lingula in patients with diffuse radiological infiltrates or with a normal chest radiograph, or in the appropriate lobe when the radiographic abnormality was localized. Total cell counts were obtained using a Neubauer's

Table 1. - Clinical details of the 5 groups

\begin{tabular}{lccccc}
\hline & $\begin{array}{c}\text { Group } 1 \mathrm{~A} \\
(\mathrm{n}=7)\end{array}$ & $\begin{array}{c}1 \mathrm{~B} \\
(\mathrm{n}=17)\end{array}$ & $\begin{array}{c}1 \mathrm{C} \\
(\mathrm{n}=8)\end{array}$ & $\begin{array}{c}\text { Non-Trauma } \\
(\mathrm{n}=9)\end{array}$ & $\begin{array}{c}\text { Control } \\
(\mathrm{n}=10)\end{array}$ \\
\hline $\mathrm{M} / \mathrm{F}$ & $7 / 0$ & $15 / 2$ & $7 / 1$ & $5 / 4$ & $9 / 1$ \\
$\mathrm{Age} \mathrm{yr}$ & $30 \pm 15$ & $37 \pm 16$ & $31 \pm 12$ & $53 \pm 14$ & $63 \pm 15$ \\
$\mathrm{PaO}_{2} / F \mathrm{IO}_{2} \mathrm{kPa}$ & $37 \pm 11.7$ & $39.3 \pm 22.9$ & $50.7 \pm 13.7$ & $30.7 \pm 16.4$ & - \\
& $(21.3-57.3)$ & $(17.3-64)$ & $(36.7-74.7)$ & $(12.8-63.3)$ & - \\
Fracture Index & $5.9 \pm 2$ & $4 \pm 2$ & $4.7 \pm 1.5$ & - & - \\
& $(3-8)$ & $(2-19)$ & $(2-7)$ & & - \\
$\mathrm{FE}$ appearance h & $75 \pm 75$ & $62 \pm 63$ & - & - & - \\
& $(11-192)$ & $(6-240)$ & & - & - \\
BAL elapse time h & $32 \pm 18$ & $40 \pm 25$ & $81 \pm 21$ & - & - \\
& $(6-60)$ & $(12-96)$ & $(24-144)$ & & - \\
\hline
\end{tabular}

Results are mean $\pm \mathrm{SD}$, ranges in brackets. FE: fat embolism, time elapsed from trauma to clinical/ radiological appearance. BAL: bronchoalvolar lavage, time elapsed from onset of FE symptoms. M: male; F: female. 
camera, and the cell viability was assessed by trypan blue dye exclusion. Differential cell counts were determined in cytocentrifuge smears stained with May-Grünwald Giemsa (Cytospin 2, Shandon). To determine the presence of fat droplets in alveolar macrophages, BAL cytocentrifuge preparations were stained with oil red $\mathrm{O}$. Four hundred macrophages were examined in a light microscope at a magnification of $\times 1,000$, and the percentage of cells with intracellular red-stained droplets was calculated.

\section{Statistical analysis}

Results are expressed as mean $\pm \mathrm{SD}$. Bronchoalveolar lavage characteristics among the five groups were analysed by analysis of variance. Sheffe's contrast test was used to examine pairs of means when the analysis of variance was significant. Significance in all data analysis was considered to be a p-value of less than 0.05 .

\section{Results}

\section{$B A L$ cell analysis}

There were no differences in BAL fluid recovery among the different groups (table 2). Total cell counts showed a trend to be higher in patients with definite FES compared to the other groups. However, whilst there was a greater percentage of neutrophils in all but the control group $(\mathrm{p}<0.01)$, no differences were shown between trauma and nontrauma patients.

\section{Identification of fat droplets in BAL cells}

Group $1 A$ - trauma patients with definite FES. Patients with definite FES (table 3) had a higher mean percentage of oil red $O$ positive macrophages $(40 \pm 24 \%$ ) (fig. 1) compared to the other groups $(\mathrm{p}<0.001)$. Based on the data obtained in the control group, a cut-off point equal to or below $3 \%$ of alveolar macrophages containing fat droplets was used to define a negative BAL for FES. Six out of the seven patients with definite FES had an increased percentage of positive oil red $\mathrm{O}$ macrophages $(>3 \%)(47 \pm 18 \%$, range $25-75 \%)$ (patients Nos. $1-6)$. In the remaining case (patient No. 7), the diagnosis of FES was established according to the presence of neurological dysfunction along with petechial rash and pulmonary infiltrates. Five patients showed a favourable outcome, but two died due to head injury and acute respiratory failure (patients Nos. 4 and 6, respectively).

Group $1 B$ - trauma patients with incomplete diagnostic criteria of FES. The final clinical diagnoses in this

Table 2. - Bronchoalveolar lavage characteristics of the study population

\begin{tabular}{|c|c|c|c|c|c|c|c|}
\hline Group & $\begin{array}{l}\text { Volume } \\
\text { recovered } \\
\mathrm{mL}\end{array}$ & $\begin{array}{l}\text { Total cells } \\
\times 10^{4} \cdot \mathrm{mL}^{-1}\end{array}$ & $\begin{array}{c}\text { Cell Viability } \\
\qquad \%\end{array}$ & $\begin{array}{c}\text { Macrophages } \\
\%\end{array}$ & $\begin{array}{c}\text { Lymphocytes } \\
\%\end{array}$ & $\begin{array}{c}\text { Neutrophils } \\
\%\end{array}$ & $\begin{array}{c}\text { Eosinophils } \\
\%\end{array}$ \\
\hline FES (1A) & $\begin{array}{c}61 \pm 14 \\
(42-74)\end{array}$ & $\begin{array}{l}232 \pm 133 \\
(57-393)\end{array}$ & $\begin{array}{c}83 \pm 11 \\
(65-93)\end{array}$ & $\begin{array}{c}66 \pm 24 \\
(33-93)\end{array}$ & $\begin{array}{l}10 \pm 11 \\
(2-34)\end{array}$ & $\begin{array}{l}23 \pm 25 \\
(5-61)\end{array}$ & $\begin{array}{c}0.6 \pm 0.8 \\
(0-2)\end{array}$ \\
\hline $\begin{array}{l}\text { Incomplete criteria } \\
\text { of FES (1B) }\end{array}$ & $\begin{array}{l}40 \pm 12 \\
(22-56)\end{array}$ & $\begin{array}{c}187 \pm 250 \\
(12-1000)\end{array}$ & $\begin{array}{c}87 \pm 8 \\
(70-98)\end{array}$ & $\begin{array}{c}62 \pm 27 \\
(8-100)\end{array}$ & $\begin{array}{c}3 \pm 3 \\
(0-10)\end{array}$ & $\begin{array}{l}34 \pm 28 \\
(0-92)\end{array}$ & $\begin{array}{l}0.5 \pm 1 \\
(0-6)\end{array}$ \\
\hline $\begin{array}{l}\text { No criteria of } \\
\text { FES (1C) }\end{array}$ & $\begin{array}{c}38 \pm 14 \\
(14-51)\end{array}$ & $\begin{array}{l}39 \pm 37 \\
(0-11)\end{array}$ & $\begin{array}{l}77 \pm 31 \\
(0-98)\end{array}$ & $\begin{array}{l}57 \pm 33 \\
(3-98)\end{array}$ & $\begin{array}{c}4 \pm 3 \\
(0-10)\end{array}$ & $\begin{array}{l}37 \pm 34 \\
(1-97)\end{array}$ & $\begin{array}{c}0.3 \pm 0.7 \\
(0-2)\end{array}$ \\
\hline $\begin{array}{l}\text { Non trauma } \\
\text { (lung filtrates) }\end{array}$ & $\begin{array}{c}49 \pm 27 \\
(29-108)\end{array}$ & $\begin{array}{l}88 \pm 120 \\
(6-385)\end{array}$ & $\begin{array}{c}76 \pm 9 \\
(61-93)\end{array}$ & $\begin{array}{l}47 \pm 37 \\
(9-92)\end{array}$ & $\begin{array}{c}7 \pm 7 \\
(0-24)\end{array}$ & $\begin{array}{l}45 \pm 35 \\
(0-85)\end{array}$ & $\begin{array}{c}0.5 \pm 0.8 \\
(0-2)\end{array}$ \\
\hline Control & $\begin{array}{c}55 \pm 9 \\
(44-68)\end{array}$ & $\begin{array}{l}96 \pm 142 \\
(3-450)\end{array}$ & $\begin{array}{c}87 \pm 15 \\
(50-99)\end{array}$ & $\begin{array}{c}94 \pm 3 * \\
(86-98)\end{array}$ & $\begin{array}{c}4 \pm 4 \\
(1-13)\end{array}$ & $\begin{array}{c}0.5 \pm 0.9 * \\
(0-3)\end{array}$ & $\begin{array}{c}0.2 \pm 0.4 \\
(0-1)\end{array}$ \\
\hline
\end{tabular}

Values are presented as mean $\pm \mathrm{sD}$, and range in parenthesis. FES: fat embolism syndrome. *: $\mathrm{p}<0.01$ with respect to other groups.

Table 3. - Characteristics and outcome of trauma patients with definite FES (1A)

\begin{tabular}{ccccccccc}
\hline $\begin{array}{c}\text { Case } \\
\text { No. }\end{array}$ & Injuries & $\begin{array}{c}\text { Neurological } \\
\text { symptoms }\end{array}$ & Petechiae $\begin{array}{c}\text { Chest } \\
\text { radiograph }\end{array}$ & $\begin{array}{c}\mathrm{Pa}_{2} \mathrm{O}_{2} / \mathrm{F}_{1} \mathrm{O}_{2} \\
\mathrm{kPa}\end{array} \mathrm{mmHg}$ & $\begin{array}{c}\text { Oil red O } \\
\%\end{array}$ & Outcome \\
\hline 1 & H,T,A & Coma & Yes & BAI & 33.6 & 252 & 75 & $\mathrm{~S}$ \\
2 & A & Coma & Not & RAI & 21.3 & 160 & 54 & $\mathrm{~S}$ \\
3 & H,T & Not & Yes & BAI & 30.3 & 227 & 52 & $\mathrm{~S}$ \\
4 & H,T & Coma & Yes & BAI & 35.6 & 267 & 46 & $\mathrm{D}$ \\
5 & H,T,A & Not & Yes & BAI & 34.4 & 258 & 29 & $\mathrm{~S}$ \\
6 & H,T,A & Coma & Yes & RAI & 57.3 & 430 & 25 & $\mathrm{D}$ \\
7 & Not & Convulsion & Yes & RAI & 47.3 & 355 & 0 & $\mathrm{~S}$ \\
\hline
\end{tabular}

FES: fat embolism syndrome; $\mathrm{Pa}_{\mathrm{a}, \mathrm{O}_{2}}$ : arterial oxygen tension; $\mathrm{FI}, \mathrm{O}_{2}$ : fractional inspiratory oxygen; $\mathrm{H}$ : head; T: thoracic; A: abdominal; BAI: bilateral lung alveolar infiltrates; RAI: right lung alveolar infiltrates; S: survived; D: died. 


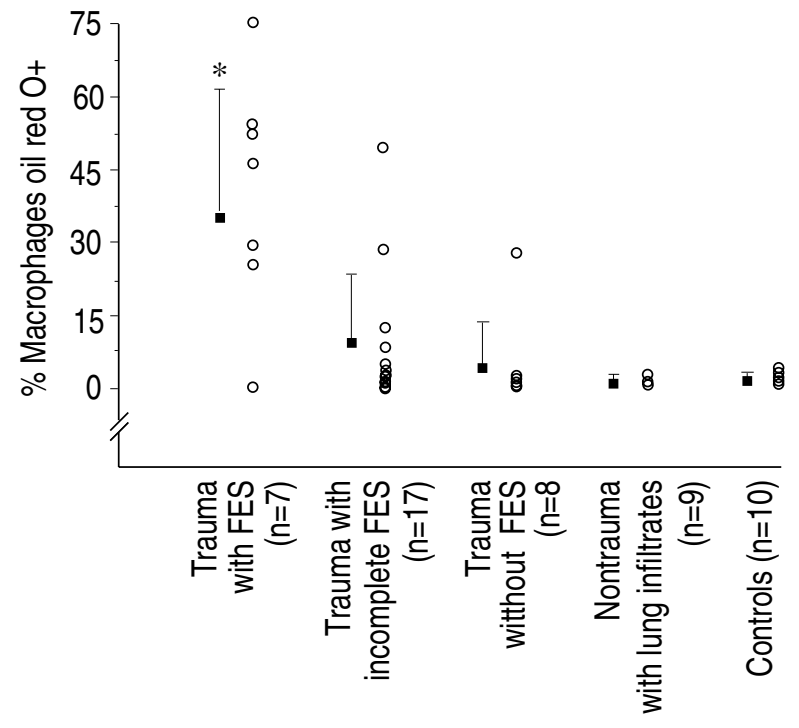

Fig. 1. - Individual (O) and mean \pm SD ( $\mathbf{\square})$ of macrophages oil red O positive in bronchoalveolar lavage of the different groups. FES: fat embolism syndrome. *: $\mathrm{p}<0.001$, with respect to the other groups.

subgroup (table 4) were as follows: pneumonia (4) (clinical and radiographic criteria as well as a positive bacterial culture from a telescoping plugged catheter); pulmonary contusion (3); adult respiratory distress syndrome (ARDS) (3) (massive blood transfusion (2) and abdominal injury (1)); and heart failure (2) (confirmed by right-sided heart catheterization). The presence of FES was suspected by the appearance of a petechial rash in four patients (patients Nos. 9, 10, 12 and 17). However, it was not possible to establish a full diagnosis of FES, since the patients did not have radiological pulmonary infiltrates or acute respiratory failure. In one patient, the aetiology of pulmonary infiltrates could not be established (patient No. 1). In this subgroup, the main percentage of oil red $\mathrm{O}$ positive macrophages was $7 \pm 13 \%$ (fig. 1). Five of the 12 (41\%) patients of this subgroup without the clinical diagnosis of FES had more than $3 \%$ of BAL positive cells (patients Nos. 2-6).

Group 1-C - Trauma patients without evidence of FES. In this subgroup, composed of eight trauma patients, the percentage of macrophages containing fat droplets was $3 \pm 9 \%$ (range $0-27 \%$ ) (fig. 1). Only one subject had more than $3 \%$ of positive macrophages in BAL (27\%), having a favourable outcome with no manifestations of FES.

Thus, BAL showed an increased number of oil red $\mathrm{O}$ positive macrophages in 6 out of $20(30 \%)$ trauma patients without the clinical diagnosis of FES (five from Group 1-B, and one from Group 1-C).

Non-trauma patients and control group. No differences in the mean percentage of oil red $\mathrm{O}$ positive macrophages were shown between nontrauma patients with acute respiratory failure and the control group $(0.5 \pm 0.9 \%$ and $0.8 \pm 1 \%$, respectively) (fig. 1 ).

\section{Sequential BAL}

Sequential BAL was carried out in two trauma patients with full diagnosis of FES (patients Nos. 3 and 5, table 3 ) who had an increased number of oil red $\mathrm{O}$ positive alveolar macrophages in BAL. Lavage was repeated at 9 and 14 days, when the clinical findings and radiographic infiltrates had considerably improved. The percentage of oil red $\mathrm{O}$ positive macrophages decreased from 52 and $29 \%$, to 24 and $0 \%$, respectively. Furthermore, in two other subjects (patients Nos. 1 and 14, table 5) a second BAL performed $48 \mathrm{~h}$ after femur surgery showing a marked increase in the percentage of oil red $\mathrm{O}$ positive macrophages ( 3 to $40 \%$ and 0 to $10 \%$, respectively) but without clinical or radiographic data suggestive of FES.

Table 4. - Characteristics and outcome of trauma patients with incomplete FES

\begin{tabular}{|c|c|c|c|c|c|c|c|c|c|}
\hline $\begin{array}{l}\text { Case } \\
\text { No. }\end{array}$ & Injuries & $\begin{array}{c}\text { Neurological } \\
\text { Symptoms }\end{array}$ & Petechiae & $\begin{array}{l}\text { Chest } \\
\text { radiograph }\end{array}$ & $\begin{array}{r}P \mathrm{a}, \mathrm{C} \\
\mathrm{kPa}\end{array}$ & $\begin{array}{l}F \mathrm{I}_{1} \mathrm{O}_{2} \\
\mathrm{mmHg}\end{array}$ & $\begin{array}{c}\text { Oil red } \mathrm{O} \\
\%\end{array}$ & $\begin{array}{c}\text { Clinical } \\
\text { diagnosis }\end{array}$ & Outcome \\
\hline 1 & $\mathrm{H}, \mathrm{T}$ & Coma & Not & BAI & 61.7 & 463 & 49 & Unknown & S \\
\hline 2 & $\mathrm{H}, \mathrm{T}$ & Coma & Not & BAI & 35.1 & 263 & 28 & Pneumonia & $\mathrm{S}$ \\
\hline 3 & $\mathrm{H}, \mathrm{T}, \mathrm{A}$ & Coma & Not & BAI & 17.3 & 130 & 12 & Pneumonia & $\mathrm{S}$ \\
\hline 4 & $\mathrm{H}, \mathrm{T}, \mathrm{A}$ & Not & Not & BAI & 31.3 & 235 & 12 & Lung contusion & $\mathrm{S}$ \\
\hline 5 & $\mathrm{H}, \mathrm{T}, \mathrm{A}$ & Not & Not & BAI & 32.4 & 243 & 8 & Cardiac failure & $\mathrm{D}$ \\
\hline 6 & $\mathrm{~T}, \mathrm{~A}$ & Not & Not & BAI & 32.3 & 242 & 4 & ARDS & $\mathrm{S}$ \\
\hline 7 & $\mathrm{H}, \mathrm{T}, \mathrm{A}$ & Coma & Not & BAI & 40.9 & 307 & 3 & ARDS & $\mathrm{S}$ \\
\hline 8 & $\mathrm{~T}$ & Confusion & Not & BAI & 39.3 & 295 & 2 & Cardiac failure & D \\
\hline 9 & $\mathrm{H}$ & Confusion & Yes & Normal & 64.0 & 480 & 1 & Unknown & $\mathrm{D}$ \\
\hline 10 & $\mathrm{H}$ & Coma & Yes & Normal & 46.8 & 351 & 1 & Unknown & $\mathrm{S}$ \\
\hline 11 & $\mathrm{~T}, \mathrm{~A}$ & Not & Not & RAI & 28.8 & 216 & 1 & Lung contusion & $S$ \\
\hline 12 & $\mathrm{H}$ & Confusion & Yes & Normal & 45.3 & 340 & 0 & Unknown & $\mathrm{S}$ \\
\hline 13 & $\mathrm{H}, \mathrm{T}, \mathrm{A}$ & Coma & Not & BAI & 32.4 & 243 & 0 & ARDS & $\mathrm{S}$ \\
\hline 14 & $\mathrm{~T}$ & Not & Not & LAI & 20.7 & 155 & 0 & Lung contusion & D \\
\hline 15 & $\mathrm{H}, \mathrm{T}, \mathrm{A}$ & Not & Not & LAI & 17.3 & 130 & 0 & Pneumonia & $\mathrm{S}$ \\
\hline 16 & $\mathrm{H}, \mathrm{T}, \mathrm{A}$ & Coma & Not & BAI & 17.6 & 132 & 0 & Pneumonia & S \\
\hline 17 & A & Confusion & Yes & Normal & 60.3 & 452 & 0 & Unknown & $\mathrm{S}$ \\
\hline
\end{tabular}

LAI: left alveolar infiltrates; ARDS: adult respiratory distress syndrome. For further abbreviations see legend to table 3. 


\section{Discussion}

Our study shows that in patients with full clinical diagnosis of FES, the percentage of oil red $\mathrm{O}$ positive macrophages was increased in six cases, whereas BAL was negative in one. In contrast, BAL showed an increased number of macrophages containing fat droplets in 6 out of 20 trauma patients without the clinical diagnosis of FES (five from Group 1-B, and one from group 1-C). It is widely accepted that some degree of pulmonary fat embolization occurs in almost all patients with longbone fractures, but only $6-10 \%$ clinically develop the full syndrome [12, 13]. Although in a recent study, Pell et al. [14] indicated that the amount of fat in the lung may determine the degree of pulmonary manifestations, the correlation between the presence of pulmonary intravascular fat and pulmonary manifestations in postmortem lung studies is poor [15]. It has been suggested that FES would occur only when the fat present in the lungs directly affects the pneumocytes, hence producing pulmonary manifestations [16]. It has been shown that pulmonary fat embolism is unrecognized in many cases because symptoms are mild or absent and chest roentgenogram can be normal [12]. Thus, the presence of oil red $\mathrm{O}$ positive macrophages by itself in BAL of trauma patients can be due to clinically silent fat embolism. However, in the five patients of group 1$\mathrm{B}$ (incomplete diagnostic criteria for FES) with pulmonary infiltrates due to aetiologies other than FES and an increased number of BAL oil red O positive cells, it is not clinically possible to exclude a mild form of FES in spite of the presence of associated pulmonary disorders.

Our results are in agreement with those of VEDRINNE et al. [8] who found high numbers of BAL oil red $\mathrm{O}$ positive macrophages in $41 \%$ of 22 trauma patients without full clinical evidence of FES. By contrast, CHASTRE et al. [7] showed that all patients with FES had a high percentage of oil red $\mathrm{O}$ positive lavage cells, whereas trauma patients without the syndrome had a normal lavage. They concluded that BAL could be a specific and sensitive tool for the diagnostic evaluation of FES. VEDRINNE et al. [8] suggested that the presence of oil red $\mathrm{O}$ positive macrophages may also be explained by parenteral nutrition, multiple organ failure, sepsis or hypertriglyceridaemia. High percentages of oil red $\mathrm{O}$ positive macrophages can also be found in patients with aspiration of gastric contents [17], a common condition in trauma patients [18]. Although patients with clinical evidence of pulmonary aspiration were excluded from our study, it has been shown that subclinical aspiration can be a common event in intubated patients [19]. However, we failed to find an increased percentage of oil red $\mathrm{O}$ positive macrophages in nontrauma patients with severe respiratory failure and all of them were intubated and under mechanical ventilation. Thus, our results agree with those of CHASTRE et al. [7], in which BAL oil red O positive cells are not present in nontrauma patients with acute respiratory failure.

In two patients with FES, sequential BAL showed that the percentage of positive macrophages decreased substantially when the clinical and pulmonary manifestations had disappeared. Furthermore, we found an increased number of BAL macrophages with fat droplets in two trauma patients without evidence of FES, after long-bone surgical intervention. These findings therefore confirm that the presence of high numbers of oil red $\mathrm{O}$ positive macrophages in BAL could be indicative of pulmonary fat embolization.

Bronchoalveolar lavage differential cell counts showed an increased percentage of neutrophils in all groups of patients, including those with no diagnostic criteria of FES and normal chest radiograph. In addition to FES [7], an increased percentage of neutrophils in BAL fluid can be found in patients with pulmonary infections or with adult respiratory distress syndrome. The presence of neutrophils in BAL fluid in patients with no pulmonary disease can be due, at least in part, to mechanical ventilation [20]. Except for the controls, all but one patient included in our study needed mechanical ventilation.

In summary, this study shows that BAL oil red $\mathrm{O}$ positive macrophages are frequently observed in trauma patients. Although it may be indicative of FES, high numbers of oil red $\mathrm{O}$ positive macrophages can also be found in patients without clinical evidence of the syndrome and could, therefore, be related to clinically silent fat embolization. Conversely, BAL cells with fat droplets are not present in nontrauma patients.

Acknowledgements: The authors are indebted to M. Carrión and M.T. Solé for their technical expertise.

\section{References}

1. Peltier LF. Fat embolism: a perspective. Clin Orthop 1988; 232: 263-270.

2. Khalfa K, Métais P. Dosage des lipides libres plasmatiques après fractures fémorales, tibiales et enclouages centro-médullaires. Ann Biol Clin 1986; 44: 397-402.

3. Burgher LW, Dines DE, Linscheid RL, Didier EP. Fat embolism and the adult respiratory distress syndrome. Mayo Clin Proc 1974; 49: 107-109.

4. Schonfeld SA, Ploysongsang Y, Dilisio R, et al. Fat embolism prophylaxis with corticosteroids: a prospective study in high risk patients. Ann Intern Med 1983; 99: 438-443.

5. Castella X, Vallés J, Cabezuelo MA, Fernandez R, Artigas A. Fat embolism syndrome and pulmonary microvascular cytology. Chest 1992; 101: 1710-1711.

6. Masson RG, Ruggieri J. Pulmonary microvascular cytology: a new diagnostic application of the pulmonary artery catheter. Chest 1985; 88: 908-914.

7. Chastre J, Fagon JY, Soler P, et al. Bronchoalveolar lavage for rapid diagnosis of the fat embolism syndrome in trauma patients. Ann Intern Med 1990; 113: 583588.

8. Vedrinne JM, Guillaume C, Gagnieu MC, Gratadour P, Fleuvert C, Motin J. Bronchoalveolar lavage in trauma patients for diagnosis of fat embolism syndrome. Chest 1992; 102: 1323-1327.

9. Gurd AR. Fat embolism: an aid to diagnosis. J Bone Joint Surg 1970; 52B: 732-737.

10. Xaubet A, Rodriguez-Roisin R, Bombi JA, Marín A, Roca J, Agustí-Vidal A. Correlation of bronchoalveolar 
lavage and clinical and functional findings in asbestosis. Am Rev Respir Dis 1986; 133: 848-854.

11. Xaubet A, Agustí C, Roca J, Picado C, Rodriguez-Roisin R. BAL lymphocyte activation antigens and diffusing capacity are related in mild to moderate pulmonary sarcoidosis. Eur Respir J 1993; 6: 715-718.

12. Emboli of extravascular tissues and secretions. In: Heitzman ER, ed. The lung: Radiologic-Pathologic Correlations. San Louis, CV Mosby, 1994; pp. 131-137.

13. Herndon JH. The syndrome of fat embolism. South J Med 1975; 58: 1577-1584.

14. Pell ACH, Hughes D, Keating J, Christie J, Busuttil A Sutherland GR. Fulminating fat embolism syndrome caused by paradoxical embolism through a patent foramen ovale. N Engl J Med 1993; 329: 926-929.

15. Dines DE, Burgher LW, Okazaki O. The clinical and pathologic correlation of fat embolism syndrome. Mayo Clin Proc 1975; 50 407-410.
16. Baker PL, Pazell JA, Peltier LF. Free fatty acids, catecholamines, and arterial hypoxia in patients with fat embolism. J Trauma 1971; 11: 1026-1030.

17. Corwin RV, Irwin RS. The lipid-laden alveolar macrophages as a marker of aspiration in parenchymal lung disease. Am Rev Respir Dis 1985; 132: 576-581.

18. Pulmonary disease caused by aspiration of solid foreign material and liquids. In: Fraser RG, Paré JAP, Paré PD, Fraser RS, Genereux GP, eds. Diagnosis of Diseases of the Chest. 3rd ed. Philadelphia, WB Saunders, 1990: pp. 2382-3416.

19. Torres A, Serra-Batlles J, Ros E, et al. Pulmonary aspiration of gastric contents in patients receiving mechanical ventilation: the effect of body position. Ann Intern Med 1992; 116: 540-543.

20. De Blasio F, Daughton DM, Thompson AB, et al. General $v s$ local anesthesia: effect on bronchoalveolar lavage findings. Chest 1993; 104: 1032-1037. 